Follis, R. H., jun. (1952). F. Pediat., 41, 713.

Freda, V. J., Vosburgh, G. J., and Di Liberti, C. (1961). Obstet. and Gynec., $18,535$.

Frerking, H. W., and Zink, O. C. (1952). Amer. F. Roentgenol., 67, 103. Gain, D. D., and Lawson, D. E. (1952). Radiology, 58, 221.

Goldfarb, A. A., and Ford, D. (1954). 7. Pediat., 44, 264.

Heys, F. M., Blattner, R. J., and Robinson, H. B. G. (1960). Ibid., 56, 234.

Jonas, W. (1959). 广. Obstet. Gynaec. Brit. Cwlth, 66, 485.

L.obstein, J. F. (1835). Quoted by Freda et al. (1961).
Looser, E. (1906). Quoted by Posner and Goldman (1957).

Malebranche (1684). Quoted by Freda et al. (1961).

Posner, A. C., and Goldman, J. A. (1957). Amer. F. Obstet. Gynec., 73, 1143.

Potter, E. L. (1952). Pathology of the Fetus and the Newborn, p. 449. Year Book Publishers, Chicago.

Ruth, E. B. (1943). Arch. Path., 36, 211.

Sarma, V. (1960). Brit. med. F., 2, 1856.

Seedorff, K. S. (1949). Quoted by Freda et al. (1961).

Vrolik, W. (1849). Quoted by Freda et al. (1961).

\title{
ABO Blood Groups and Staphylococcal Infection
}

\author{
A. J. ZUCKERMAN,* M.B., M.sC.; D. L. MILLER,* M.B.; J. C. MCDONALD,** M.D.
}

Brit. med. F., 1964, 1, 101

The presence of blood-group-like substances in bacteria was first noted in shigellae and pneumococci by Eisler $(1930,1931)$; they have since been demonstrated in several species (Springer et al., 1961). Illchmann-Christ and Nagel (1954) found that anti- $\mathrm{A}$ antibody was removed from $\mathrm{O}$ and $\mathrm{B}$ sera by staphylococci and postulated that staphylococci possessed an A-like receptor. If this were so, persons belonging to blood-group A might carry staphylococci in the nose more frequently than those of other groups or have an increased susceptibility to staphylococcal infections, owing to an inability to produce anti-A antibody. This hypothesis was not supported by Coulter's (1962) finding of a significant excess of blood group O in nasal carriers and in women with a history of staphylococcal infection in a maternity hospital in Australia. White and Shooter (1962) found a slight but not significant group $O$ excess among nasal carriers and patients with wound sepsis in male surgical patients in a London hospital.

As the result of a comprehensive survey made in 1959-60 of staphylococcal nasal carriage and infection in Royal Air Force recruits we also had the opportunity to examine this question. The field and laboratory methods used in the survey have been described (Miller et al., 1962). The recruits' ABO and rhesus blood group and place of birth were obtained from their medical records. The blood group and the result of at least one nasal swab examination were available for 2,226 recruits born within the British Isles; second swabs had been examined from 1,466 of these men.

To serve as a control Dr. A. C. Kopéc, of the Nuffield Blood Group Centre, kindly supplied an analysis of the distribution of blood groups for a sample of 47,108 R.A.F. recruits tested by the service during 1956-61. The study population and controls were divided into three groups according to their place of birth, as described in other studies of blood group and infection (McDonald and Zuckerman, 1962 ; Zuckerman and McDonald, 1963), and the statistical significance of the difference between the observed and expected distributions was tested by the same method (Woolf, 1955).

\section{Results}

The distribution of the $\mathrm{ABO}$ blood groups and rhesus factor in the 2,226 recruits was analysed in six main groups (Table I). The observed percentages of carriers and non-carriers in each ABO blood group, making due allowance for the regional constitution of the observed groups, showed no significant

\footnotetext{
- From the Epidemiological Research Laboratory, Central Public Health Laboratory, Colindale, London.
}

differences from the expected proportions calculated from the control figures. This was equally true in all geographical regions. The proportion of $\mathrm{Rh}$-negative recruits in each geographical region showed only minor variations. Among the 133 men who experienced a septic lesion during the period of observation there was a small excess of persons in blood-group A (Table II), but this was not significant.

We conclude that there is no association between ABO blood group and susceptibility to staphylococcal nasal carriage or infection.

TABLE I.-Observed (O) and Expected (E) Blood-group Distributions in Relation to the Nasal Carriage of Staphylococcus aureus

\begin{tabular}{|c|c|c|c|c|c|c|c|c|c|}
\hline \multirow{2}{*}{$\begin{array}{l}\text { Staphylococcal } \\
\text { Carrier State }\end{array}$} & \multirow{2}{*}{$\begin{array}{l}\text { No. of } \\
\text { Men }\end{array}$} & \multicolumn{2}{|c|}{ Group $\mathrm{O}$} & \multicolumn{2}{|c|}{ Group A } & \multicolumn{2}{|c|}{ Group B } & \multicolumn{2}{|c|}{ Group AB } \\
\hline & & (\%) & $\underset{(\%)}{E}$ & $\begin{array}{l}\mathrm{O} \\
(\%)\end{array}$ & $\begin{array}{c}\mathrm{E} \\
(\%)\end{array}$ & (\%) & $\underset{(\%)}{\mathrm{E}}$ & (\%) & $\begin{array}{c}\mathrm{E} \\
(\%)\end{array}$ \\
\hline $\mathrm{ca}$ & 988 & $47 \cdot 4$ & $46 \cdot 5$ & $42 \cdot 7$ & $41 \cdot 7$ & $7 \cdot 4$ & $8 \cdot 8$ & 2.5 & 3.0 \\
\hline Carrie & $\begin{array}{r}1,238 \\
454\end{array}$ & $\begin{array}{l}44 \cdot 5 \\
46 \cdot 7\end{array}$ & $\begin{array}{l}46 \cdot 4 \\
46 \cdot 5\end{array}$ & $\begin{array}{l}43 \cdot 2 \\
42 \cdot 3\end{array}$ & $\begin{array}{l}41 \cdot 9 \\
41.6\end{array}$ & $\begin{array}{l}9 \cdot 0 \\
8 \cdot 1\end{array}$ & $\begin{array}{l}8 \cdot 7 \\
8 \cdot 8\end{array}$ & $\begin{array}{l}3 \cdot 3 \\
2 \cdot 9\end{array}$ & $\begin{array}{l}3.0 \\
2.9\end{array}$ \\
\hline $\begin{array}{l}\text { Non-carriers on both } \\
\text { swabs }\end{array}$ & 669 & $45 \cdot 4$ & $46 \cdot 1$ & 42.5 & $42 \cdot 0$ & $8 \cdot 4$ & $8 \cdot 7$ & 3.7 & 3.1 \\
\hline $\begin{array}{l}\text { First swab positive, } \\
\text { second swab negative }\end{array}$ & 186 & $47 \cdot 3$ & $46 \cdot 2$ & $45 \cdot 2$ & $42 \cdot 3$ & ${ }^{*}$ & & * & \\
\hline second swab positive & 157 & 46.5 & $46 \cdot 5$ & $40 \cdot 1$ & $41 \cdot 4$ & - & & - & \\
\hline
\end{tabular}

* Numbers of men insufficient for analysis.

Note : The detailed figures on which this table is based are available on request.

TABLE II.-Observed and Fxpected Blood-group Distributions in 133

\begin{tabular}{|c|c|c|c|}
\hline & & Observed (\%) & Expected (\%) \\
\hline $\begin{array}{cc}\text { Group O } \\
\Rightarrow & \text { A } \\
" & \text { B } \\
\# & \text { AB }\end{array}$ & $\begin{array}{ll}\ldots & \ldots \\
\cdots & \cdots \\
\cdots & \cdots \\
\cdots & \cdots\end{array}$ & $\begin{array}{r}44 \cdot 4 \\
47 \cdot 4 \\
5 \cdot 3 \\
3 \cdot 0\end{array}$ & $\begin{array}{r}45 \cdot 9 \\
42 \cdot 1 \\
8 \cdot 3 \\
3 \cdot 0\end{array}$ \\
\hline
\end{tabular}

We are indebted to Mrs. Judith Munk for her help with the statistical analysis and to the Director-General of the Royal Air Force Medical Services for permission to publish this report.

\section{REFERENCES}

Coulter, J. R. (1962). Nature (Lond.), 195, 301. Eisler, M. (1930). Z. Immun.-Forsch., 67, 38. - (1931). Ibid., 73, 37.

Illchmann-Christ, A., and Nagel, V. (1954). Ibid., 111, 307.

McDonald, J. C., and Zuckerman, A. J. (1962). Brit. med. F., 2, 89.

Miller, D. L., McDonald, J. C., Jevons, M. P., and Williams, R. E. $\mathbf{O}$. (1962). F. Hyg. (Lond.), 60, 451.

Springer, G. F., Williamson, P., and Brandes, W. C. (1961). \}. exp. Med., 113, 1077.

White, H., and Shooter, R. A. (1962). Brit. med. F., 2, 307

Woolf, B. (1955). Ann. hum. Genet., 19, 251.

Zuckerman, A. J., and McDonald, J. C. (1963). Brit. med. F., 2, 537. 